\title{
Journal of Pharmacy
}

\section{Stability of extemporaneous rifampicin prepared with X-temp ${ }^{\circledR}$ oral suspension system.}

\author{
Salma Nadirah Md Salim ${ }^{1}$, Mohd Danial Mohd Murshid ${ }^{1}$ and Amirah Mohd Gazzali1,
}

\section{ABSTRACT}

Introduction: Rifampicin is a first line antituberculosis drug that is commonly used in the treatment of tuberculosis, both in adults and paediatric patients. However, there is a lack of liquid formulation for rifampicin in the market due to the small market size and the physicochemical properties of the drug itself. An innovative new mix called X-Temp® oral suspension system (OSS) has been available in the market as a choice of vehicle for extemporaneous suspension.

Aim: The aim of this study was to prepare rifampicin suspension in the X-Tempß OSS and evaluate its stability following storage at two temperatures - refrigerated $\left(5^{\circ} \mathrm{C} \pm 3{ }^{\circ} \mathrm{C}\right)$ and in a stability chamber $\left(30^{\circ} \mathrm{C} \pm 2{ }^{\circ} \mathrm{C} / \mathrm{RH} 75 \% \pm 5 \%\right)$.

Materials and method: This study investigates the physicochemical and microbiological stability of rifampicin formulated in X-temp® OSS. The rifampicin suspension was prepared at $25 \mathrm{mg} / \mathrm{ml}$ and kept in two types of amber-coloured storage bottles. The bottles were stored in an open and close storage system at $5{ }^{\circ} \mathrm{C}$ (refrigeration) and $30^{\circ} \mathrm{C} / 75 \% \mathrm{RH}$ (non-refrigerated) and the stability of the product was evaluated at specified time intervals.

Results: It was found that the content of rifampicin remained above $90 \%$ of the original concentration throughout the study as required by the standard references. Visual appearance, colour, odour and $\mathrm{pH}$ remained unchanged throughout the study period and the extemporaneous preparation was not susceptible to microbial contamination.

Conclusion: Results from this stability study confirmed that the X-temp® OSS is a suitable vehicle for the preparation of extemporaneous rifampicin liquid formulation.

\section{ARTICLE HISTORY:}

Received: 16 August 2020

Accepted: 26 October 2020

Published: 8 January 2021

\section{KEYWORDS:}

Extemporaneous, rifampicin, $X-$ temp ${ }^{\circledR}$, suspension, tuberculosis.

\section{HOW TO CITE THIS \\ ARTICLE:}

Md Salim, S. N., Murshid, M. D. M. \& Gazzali, A. M. (2021). Stability of extemporaneous rifampicin prepared with X-temp ${ }^{\circledR}$ oral suspension system. Journal of Pharmacy, 1(1), 54-62.

\section{*Corresponding author:}

Email address: amirahmg@usm.my Tel:+ 60194883800

\author{
Authors' Affiliation: \\ ${ }^{1}$ Department of Pharmaceutical Technology, School of Pharmaceutical \\ Sciences, Universiti Sains Malaysia, 11800 Minden, Penang, Malaysia.
}

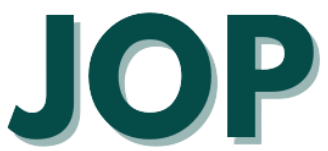




\section{Introduction}

Extemporaneous preparations or compounding is defined as the mixing of ingredients listed in a prescription or drug formula. This term generally refers to a manual process, performed for individual orders and specific patients (Quick et al., 1997). Although not being conducted often in the current pharmacy practice, it remains an important area that needs to be taken care of by pharmacists. Extemporaneous products usually need to be prepared for certain patient populations who may have special clinical needs, which could not be met by licensed medicinal products available in the markets. In addition, the fact that certain medications are not available in paediatric-friendly dosage forms also necessitate reformulation by pharmacists as extemporaneous preparations.

Stability of extemporaneous preparation is an important factor that needs to be considered by formulation pharmacists. Since the preparations are unlicensed, the safety risks are higher (Jackson \& Lowey, 2010) and hence it is very important to ensure that the formulation is stable and safe for consumption. Common extemporaneous preparations are usually evaluated to ensure their stability as a way to support the practice.

Rifampicin or also known as rifampin is a first line antituberculosis (TB) drug and is important in the treatment of TB during both the active and continuous phases. It has a very low water solubility $(1400 \mathrm{mg} / \mathrm{L}$ at 25 $\left.{ }^{\circ} \mathrm{C}\right)$ with high susceptibility to photodegradation in aqueous form (Yalkowsky \& He, 2003). It is also unstable in the presence of heat, air and moisture (Osol, Hoover, \& et al., 1975).

In clinical settings, rifampicin is commonly available in capsule form whilst oral liquid products for paediatric are rarely produced, which might be related to its instability problems (Glass \& Haywood, 2006). Hence, it is a common practice to prepare rifampicin extemporaneously in hospitals, clinics and pharmacies for this specific population. This practice has its challenges to ensure good acceptance and compliance from patients due to several issues such as poor palatability and dispersibility in aqueous solution. To ensure good dispersibility, rifampicin is commonly formulated as suspension with suitable suspending agents and thickeners. One particular study by Nahata et al. (1994) described the difficulty to withdraw the prescribed amount of rifampicin from extemporaneous preparations due to problems of powder wetting and dispersion faced by syrup-based formulations. They reported that the presence of a suspending agent is important to ensure accurate dosing each time.

Stability of extemporaneous rifampicin is also being described in the literature. Rifampicin is light-, heat-, airand moisture-sensitive, hence this may lead to challenges in the storage of its liquid preparations. Readers are directed to other publications that discuss the stability of extemporaneously prepared rifampicin suspensions (Glass \& Haywood, 2006; Krukenberg, Mischler, Massad, Moore, \& Chandler, 1986; Nahata, Morosco, \& Hipple, 1994).

Currently in the clinical settings, rifampicin oral liquid products are commonly prepared by using syrups such as simple syrup and cherry syrup. The mixture of OraSweet ${ }^{\circledR}$ and Ora-Plus ${ }^{\circledR}$ syrups are also being suggested. In recent years, an innovative and new mix called XTemp ${ }^{\circledR}$ oral suspension system (OSS) has been available in the market as a choice of vehicle for extemporaneous syrup and suspension. It is a complete OSS with suspending agent, stabilizer and is mildly flavoured (orange flavour), with minimal preservation. The availability of this OSS could help to accelerate the preparation process of extemporaneous products and potentially offer good stability and palatability of the prepared product. The presence of suspending agents in XTemp ${ }^{\circledR}$ has made it a suitable carrier to be used in the extemporaneous preparation of low water-soluble drug powder such as rifampicin.

However, with the multiple problems associated with rifampicin stability, a study on rifampicin in X-Temp ${ }^{\circledR}$ OSS is needed. Hence, this study was designed to ensure that the OSS has the ability to preserve rifampicin efficiently. We decided to conduct the stability study independently to investigate the suitability of X-Temp ${ }^{\circledR}$ as a carrier for rifampicin. The aim of this study was to prepare rifampicin suspension in the X-Temp ${ }^{\circledR}$ OSS and evaluate its stability following storage at two temperatures - refrigerated $\left(5^{\circ} \mathrm{C} \pm 3{ }^{\circ} \mathrm{C}\right)$ and in a stability chamber $(30$ ${ }^{\circ} \mathrm{C} \pm 2{ }^{\circ} \mathrm{C} / \mathrm{RH} 75 \% \pm 5 \%$ ). The product was kept in either a plastic or a glass bottle and parameters including physical characteristics (colour, clarity and odour), $\mathrm{pH}$, microbial presence and available concentration were evaluated at specific time intervals in two systems; open and closed systems. Detailed methods and results are presented in the following sections.

\section{Materials and Methods}

\section{Materials and Instruments}

Rifampicin capsules $300 \mathrm{mg}$ (Rifasynt ${ }^{\circledR}$ ), X-temp ${ }^{\circledR}$ OSS and HDPE plastic bottles were obtained from BioScenergy International Pv. Ltd. Methanol (QRëc $\left.{ }^{\circledR}\right)$ was of AR grade and was used as received. Nutrient agar (Merck, Darmstadt, Germany) was used for microbial tests. UV/Vis spectrophotometer (Kinesis Hitachi Model U-2800, Leicestershire, UK) was used to evaluate the concentration of rifampicin in the OSS, $\mathrm{pH}$ meter (Hanna Precision $\mathrm{pH}$ meter Model pH 211, Merck, Darmstadt, Germany) was used to assess the $\mathrm{pH}$ value of the preparation. A designated stability chamber was used to 
store the preparation.

\section{Preparation of rifampicin OOS}

Rifampicin capsules were opened in order to obtain the powder. The powder then was mixed with OSS in a mortar according to the amount and concentration needed. Rifampicin OSS was prepared at a concentration of 25 $\mathrm{mg} / \mathrm{mL}$ by using $300 \mathrm{mg}$ rifampicin capsules. The method used for mixing these two ingredients is the geometric dilution whereby the rifampicin capsule content was triturated in a portion of syrup, syrup was added bit by bit until it becomes a slurry paste, the slurry paste was retriturated and the remaining syrup was added gradually while mixing. Both open and close systems experiments were conducted in two types of container; glass and plastic bottle.

\section{Open system}

Rifampicin OSS were prepared and stored in glass and plastic bottles, each containing $300 \mathrm{~mL}$ of the product at a concentration of $25 \mathrm{mg} / \mathrm{mL}$. The bottles were kept at two different temperatures, $5{ }^{\circ} \mathrm{C} \pm 3{ }^{\circ} \mathrm{C}$ (refrigerated) and 30 ${ }^{\circ} \mathrm{C} \pm 2{ }^{\circ} \mathrm{C} / \mathrm{RH} 75 \% \pm 5 \%$ (non-refrigerated) (ASEAN Guidelines on Stability Study of Drug Product). Each day, $4 \mathrm{~mL}$ (equal to $100 \mathrm{mg}$ of rifampicin) was withdrawn and transferred into an empty bottle, to simulate the patient's behaviour of opening, withdrawing and closing the bottle every day. At a specific time interval $(0,7,14,30,60$ days $)$, the samples withdrawn were evaluated for the physical characteristics (colour, clarity and odour), $\mathrm{pH}$ value, rifampicin concentration and microbial presence, as explained in the following subsections. All experiments were conducted in triplicates $(n=3)$.

\section{Close system}

Rifampicin OSS were prepared and stored in glass and plastic bottles, each containing $50 \mathrm{~mL}$ of the product. The bottles were kept at two different temperatures, $5{ }^{\circ} \mathrm{C}$ $\pm 3{ }^{\circ} \mathrm{C}$ (refrigerated) and $30{ }^{\circ} \mathrm{C} \pm 2{ }^{\circ} \mathrm{C} / \mathrm{RH} 75 \% \pm 5 \%$ (nonrefrigerated). At a specific time interval $(0,14,30,60,90$ days), three bottles from each group were evaluated for the physical characteristics (colour, clarity and odour), $\mathrm{pH}$ value, rifampicin concentration and microbial presence, as explained in the following subsections. All experiments were conducted in triplicates $(n=3)$.

\section{Evaluation of physical characteristics and $\mathrm{pH}$ value}

The physical appearance of the withdrawn suspension was inspected at each time point and was compared with the characteristics recorded at day 0 . The suspensions were then shaken well to ensure homogenous dispersion and the required volume was withdrawn from the bottles. No bubble was retained after shaking. The $\mathrm{pH}$ value of the product was measured by using a $\mathrm{pH}$ meter at each time point. Any changes were recorded accordingly.

\section{Evaluation of rifampicin concentration}

The concentration of rifampicin at each time point was determined through spectrophotometry approach. Briefly, $0.1 \mathrm{~mL}$ of rifampicin OSS was diluted in $10 \mathrm{~mL}$ of methanol (primary dilution) and subsequently $0.1 \mathrm{~mL}$ from the primary dilution was further diluted with $10 \mathrm{~mL}$ of methanol (secondary dilution). The absorbance of the secondary dilution was measured at $480 \mathrm{~nm}$ and the amount of rifampicin presence in the product was calculated in reference to a standard calibration curve of rifampicin prepared at $5,10,15,20$ and $25 \mu \mathrm{g} / \mathrm{ml}\left(\mathrm{R}^{2}=\right.$ 0.9983).

\section{Evaluation of microbial presence}

This test was conducted to determine the presence of Escherichia coli, aerobic bacteria, yeast and mould in the product. A culture media was prepared by dissolving $3 \mathrm{~g}$ of nutrient agar dehydrated powder in $150 \mathrm{~mL}$ of distilled water. The suspension was boiled and kept under vigorous stirring. The solubilized agar was then sterilized by autoclaving at $121{ }^{\circ} \mathrm{C}$ for 15 minutes. Subsequently, 0.1 $\mathrm{mL}$ of the tested product was pipetted into a sterile petri dish and the agar was then poured into the same dish, before being placed in an incubator at $37^{\circ} \mathrm{C}$ for 2 days (Europe, 2011).

\section{Results}

The experiments were conducted to determine the potential of X-temp ${ }^{\circledR}$ OSS to produce a stable extemporaneous oral liquid product of rifampicin. The U.S Pharmacopeia and European Pharmacopeia standard was used as a reference in determining the level of rifampicin concentration needed to be present in the product throughout storage and the microbial limit that is allowed to be available in such a product. The calibration curve of rifampicin was prepared between 5 to $25 \mu \mathrm{g} / \mathrm{mL}$ and this range is within the linear range of rifampicin as reported in the literature (Tilinca et al., 2017).

\section{Open system}

As presented in Table $\mathbf{1}$ and $\mathbf{2}$, the physical characteristics (of the suspension remained unchanged throughout the study period (60 days) for both glass and plastic bottles. The $\mathrm{pH}$ of the suspension was maintained between 4.17 to 4.35 for plastic bottles and 4.17 to 4.33 for glass bottles, showing no obvious $\mathrm{pH}$ changes in 60 days. The concentration of rifampicin in the preparation was also successfully maintained between the accepted ranges of $90 \%$ to $110 \%$. Microbial growth was also absent. This finding was observed for both storage conditions, showing that the X-Temp ${ }^{\circledR}$ OSS has the ability to preserve and stabilize the rifampicin suspension in 60 days, in an open system. The overall stability data are summarized in Figure 1, Figure 2, Table 1 and Table 2. 


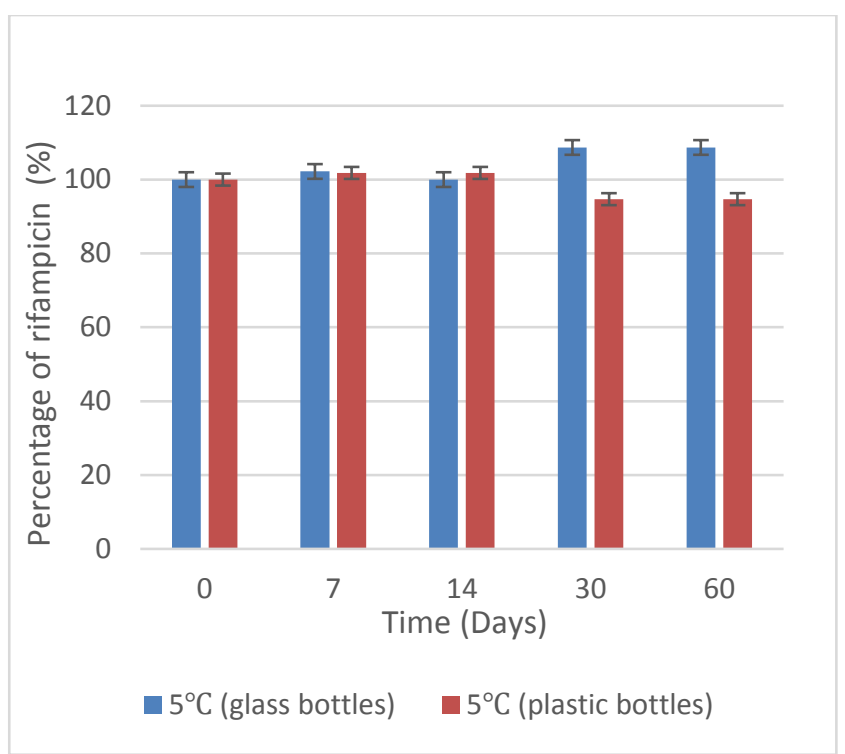

Figure 1: The comparison of rifampicin concentration (\%) against time (days) in open system at temperature $5^{\circ} \mathrm{C}(\mathrm{n} \geq 3)$

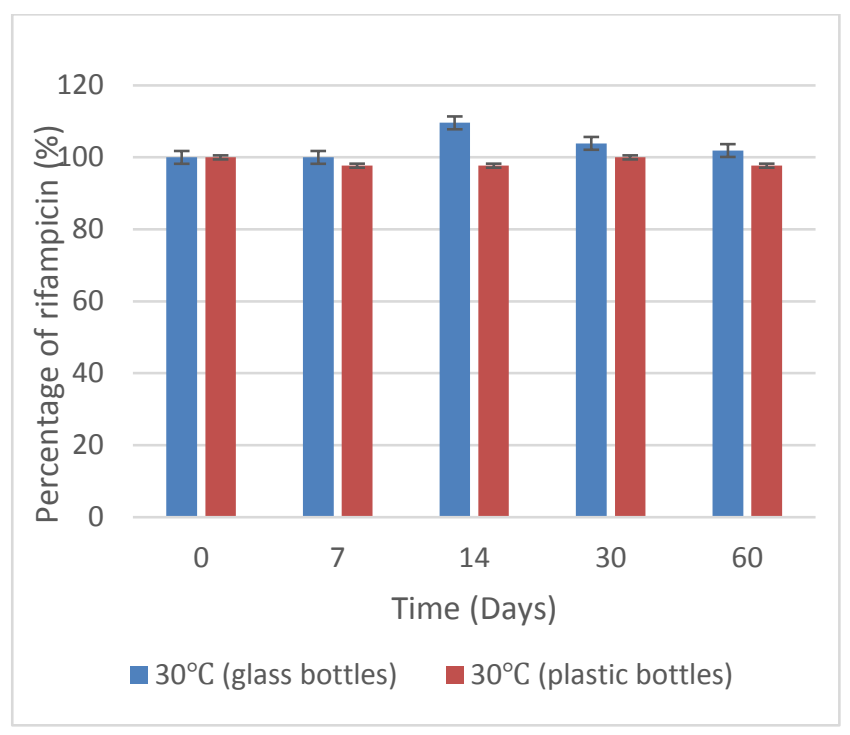

Figure 2: The comparison of rifampicin concentration (\%) against time (days) in open system at temperature $30{ }^{\circ} \mathrm{C}(\mathrm{n} \geq 3)$

\section{Close system}

The physical characteristics of rifampicin suspension stored under close system were also maintained throughout the 90 days study period. Fluctuations in terms of concentration could be seen as presented in Figure 3 and Figure 4. The overall characteristics of the rifampicin OSS is presented in Table $\mathbf{3}$ and 4, for plastic and glass bottles respectively.

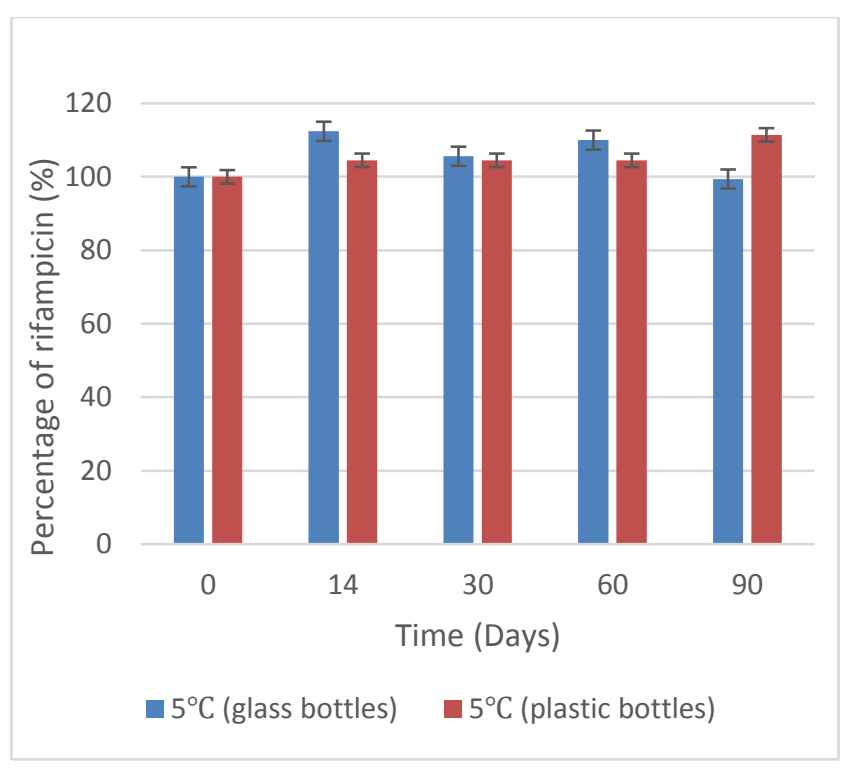

Figure 3: The comparison of rifampicin concentration (\%) against time (days) in close system at temperature $5{ }^{\circ} \mathrm{C}(\mathrm{n} \geq 3)$

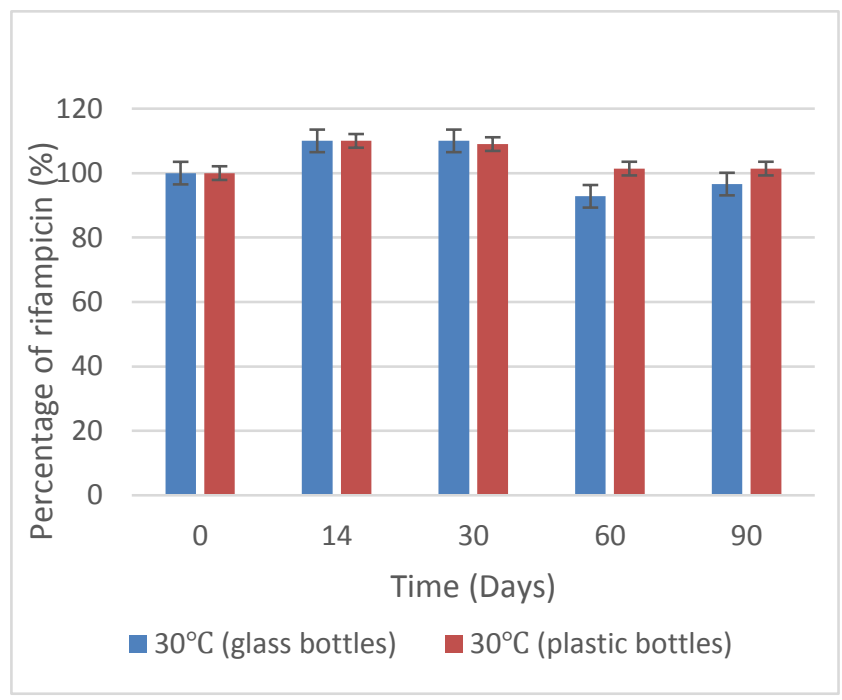

Figure 4: The comparison of rifampicin concentration (\%) against time (days) in close system at temperature $30{ }^{\circ} \mathrm{C}(\mathrm{n} \geq 3)$ 
Table 1: Open system/plastic bottle

\begin{tabular}{|c|c|c|c|c|c|c|c|}
\hline \multirow[t]{2}{*}{ Test } & \multirow[t]{2}{*}{ Specification } & \multirow[t]{2}{*}{ Temperature } & \multicolumn{5}{|c|}{ Time (Days) } \\
\hline & & & 0 & 7 & 14 & 30 & 60 \\
\hline $\begin{array}{l}\text { Visual } \\
\text { appearance }\end{array}$ & $\begin{array}{l}\text { Colour: Red } \\
\text { Clarity: Opaque } \\
\text { Odour: Orange }\end{array}$ & $\begin{array}{l}2-8^{\circ} \mathrm{C} \\
30{ }^{\circ} \mathrm{C}\end{array}$ & $\begin{array}{l}\text { Red, Opaque, } \\
\text { Orange } \\
\text { Red, Opaque, } \\
\text { Orange }\end{array}$ & $\begin{array}{l}\text { Red, Opaque, } \\
\text { Orange } \\
\text { Red, Opaque, } \\
\text { Orange }\end{array}$ & $\begin{array}{l}\text { Red, Opaque, } \\
\text { Orange } \\
\text { Red, Opaque, } \\
\text { Orange }\end{array}$ & $\begin{array}{l}\text { Red, Opaque, } \\
\text { Orange } \\
\text { Red, Opaque, } \\
\text { Orange }\end{array}$ & $\begin{array}{l}\text { Red, Opaque, } \\
\text { Orange } \\
\text { Red, Opaque, } \\
\text { Orange }\end{array}$ \\
\hline pH & 4 to 5 & $\begin{array}{l}2-8^{\circ} \mathrm{C} \\
30{ }^{\circ} \mathrm{C}\end{array}$ & $\begin{array}{l}4.29 \\
4.17\end{array}$ & $\begin{array}{l}4.29 \\
4.25\end{array}$ & $\begin{array}{l}4.23 \\
4.31\end{array}$ & $\begin{array}{l}4.23 \\
4.33\end{array}$ & $\begin{array}{l}4.37 \\
4.35\end{array}$ \\
\hline Assay & $\begin{array}{l}90.0 \% \text { to } 110.0 \% \text { (USP } 2013) \\
\pm \mathrm{SEM}\end{array}$ & $\begin{array}{l}2-8^{\circ} \mathrm{C} \\
30{ }^{\circ} \mathrm{C}\end{array}$ & $\begin{array}{l}100.0 \% \pm 0.0 \\
100.0 \% \pm 0.0\end{array}$ & $\begin{array}{l}101.8 \% \pm 5.6 \\
97.7 \% \pm 5.9\end{array}$ & $\begin{array}{l}101.8 \% \pm 3.1 \\
97.7 \% \pm 4.7\end{array}$ & $\begin{array}{l}94.7 \% \pm 4.1 \\
100.0 \% \pm 2.3\end{array}$ & $\begin{array}{l}94.7 \% \pm 4.1 \\
97.7 \% \pm 0.7\end{array}$ \\
\hline $\begin{array}{l}\text { Microbial } \\
\text { limit }\end{array}$ & $\begin{array}{l}\text { Aerobic bacteria }<1000 \mathrm{cfu} / \mathrm{g} \\
\text { Yeast } \& \text { mould }<100 \mathrm{cfu} / \mathrm{g}\end{array}$ & $\begin{array}{l}2-8^{\circ} \mathrm{C} \\
30^{\circ} \mathrm{C}\end{array}$ & $\begin{array}{l}\text { Conforms } \\
\text { Conforms }\end{array}$ & $\begin{array}{l}\text { Conforms } \\
\text { Conforms }\end{array}$ & $\begin{array}{l}\text { Conforms } \\
\text { Conforms }\end{array}$ & $\begin{array}{l}\text { Conforms } \\
\text { Conforms }\end{array}$ & $\begin{array}{l}\text { Conforms } \\
\text { Conforms }\end{array}$ \\
\hline
\end{tabular}

Table 2: Open system/glass bottle

\begin{tabular}{|c|c|c|c|c|c|c|c|}
\hline \multirow[t]{2}{*}{ Test } & \multirow[t]{2}{*}{ Specification } & \multirow[t]{2}{*}{ Temperature } & \multicolumn{5}{|c|}{ Time (Days) } \\
\hline & & & 0 & 7 & 14 & 30 & 60 \\
\hline \multirow[t]{2}{*}{$\begin{array}{l}\text { Visual } \\
\text { appearance }\end{array}$} & $\begin{array}{l}\text { Colour: Red } \\
\text { Clarity: Opaque }\end{array}$ & $2-8^{\circ} \mathrm{C}$ & Red, Opaque, & Red, Opaque, & Red, Opaque, & Red, Opaque, & Red, Opaque, \\
\hline & Odour: Orange & $30^{\circ} \mathrm{C}$ & $\begin{array}{l}\text { Red, Opaque, } \\
\text { Orange }\end{array}$ & $\begin{array}{l}\text { Red, Opaque, } \\
\text { Orange }\end{array}$ & $\begin{array}{l}\text { Red, Opaque, } \\
\text { Orange }\end{array}$ & $\begin{array}{l}\text { Red, Opaque, } \\
\text { Orange }\end{array}$ & $\begin{array}{l}\text { Red, Opaque, } \\
\text { Orange }\end{array}$ \\
\hline \multirow[t]{2}{*}{ pH } & 4 to 5 & $2-8^{\circ} \mathrm{C}$ & 4.31 & 4.23 & 4.17 & 4.17 & 4.33 \\
\hline & & $30{ }^{\circ} \mathrm{C}$ & 4.19 & 4.25 & 4.38 & 4.30 & 4.38 \\
\hline \multirow[t]{2}{*}{ Assay } & $90.0 \%$ to $110.0 \%$ (USP 2013$)$ & $2-8^{\circ} \mathrm{C}$ & $100.0 \% \pm 0.0$ & $102.2 \% \pm 6.3$ & $100.0 \% \pm 12.6$ & $108.7 \% \pm 4.7$ & $108.7 \% \pm 4.7$ \\
\hline & $\pm \mathrm{SEM}$ & $30^{\circ} \mathrm{C}$ & $100.0 \% \pm 0.0$ & $100.0 \% \pm 5.8$ & $109.6 \% \pm 3.5$ & $103.9 \% \pm 0.6$ & $101.9 \% \pm 5.7$ \\
\hline \multirow{2}{*}{$\begin{array}{l}\text { Microbial } \\
\text { limit }\end{array}$} & Aerobic bacteria $<1000 \mathrm{cfu} / \mathrm{g}$ & $2-8^{\circ} \mathrm{C}$ & Conforms & Conforms & Conforms & Conforms & Conforms \\
\hline & Yeast \& mould $<100 \mathrm{cfu} / \mathrm{g}$ & $30^{\circ} \mathrm{C}$ & Conforms & Conforms & Conforms & Conforms & Conforms \\
\hline
\end{tabular}


Table 3: Close system/plastic bottle

\begin{tabular}{|c|c|c|c|c|c|c|c|}
\hline \multirow[t]{2}{*}{ Test } & \multirow[t]{2}{*}{ Specification } & \multirow[t]{2}{*}{ Temperature } & \multicolumn{5}{|c|}{ Time (Days) } \\
\hline & & & 0 & 14 & 30 & 60 & 90 \\
\hline \multirow[t]{2}{*}{$\begin{array}{l}\text { Visual } \\
\text { appearance }\end{array}$} & $\begin{array}{l}\text { Colour: Red } \\
\text { Clarity: Opaque }\end{array}$ & $2-8^{\circ} \mathrm{C}$ & $\begin{array}{l}\text { Red, Opaque, } \\
\text { Orange }\end{array}$ & $\begin{array}{l}\text { Red, Opaque, } \\
\text { Orange }\end{array}$ & $\begin{array}{l}\text { Red, Opaque, } \\
\text { Orange }\end{array}$ & $\begin{array}{l}\text { Red, Opaque, } \\
\text { Orange }\end{array}$ & $\begin{array}{l}\text { Red, Opaque, } \\
\text { Orange }\end{array}$ \\
\hline & Odour: Orange & $30^{\circ} \mathrm{C}$ & $\begin{array}{l}\text { Red, Opaque, } \\
\text { Orange }\end{array}$ & $\begin{array}{l}\text { Red, Opaque, } \\
\text { Orange }\end{array}$ & $\begin{array}{l}\text { Red, Opaque, } \\
\text { Orange }\end{array}$ & $\begin{array}{l}\text { Red, Opaque, } \\
\text { Orange }\end{array}$ & $\begin{array}{l}\text { Red, Opaque, } \\
\text { Orange }\end{array}$ \\
\hline \multirow[t]{2}{*}{ pH } & 4 to 5 & $2-8^{\circ} \mathrm{C}$ & 4.17 & 4.17 & 4.16 & 4.16 & 4.36 \\
\hline & & $30^{\circ} \mathrm{C}$ & 4.17 & 4.65 & 4.70 & 4.78 & 4.79 \\
\hline \multirow[t]{2}{*}{ Assay } & $90.0 \%$ to $110.0 \%$ (USP 2013 ) & $2-8^{\circ} \mathrm{C}$ & $100.0 \% \pm 0.0$ & $104.5 \% \pm 8.2$ & $104.5 \% \pm 8.2$ & $104.5 \% \pm 8.2$ & $110.0 \% \pm 8.1$ \\
\hline & $\pm \mathrm{SEM}$ & $30^{\circ} \mathrm{C}$ & $100.0 \% \pm 0.0$ & $110.0 \% \pm 30.8$ & $109.0 \% \pm 0.9$ & $101.4 \% \pm 3.9$ & $101.4 \% \pm 4.6$ \\
\hline \multirow{2}{*}{$\begin{array}{l}\text { Microbial } \\
\text { limit }\end{array}$} & Aerobic bacteria $<1000 \mathrm{cfu} / \mathrm{g}$ & $2-8^{\circ} \mathrm{C}$ & Conforms & Conforms & Conforms & Conforms & Conforms \\
\hline & Yeast \& mould $<100 \mathrm{cfu} / \mathrm{g}$ & $30^{\circ} \mathrm{C}$ & Conforms & Conforms & Conforms & Conforms & Conforms \\
\hline
\end{tabular}

Table 4: Close system/glass bottle

\begin{tabular}{|c|c|c|c|c|c|c|c|}
\hline \multirow[t]{2}{*}{ Test } & \multirow{2}{*}{ Specification } & \multirow{2}{*}{ Temperature } & \multicolumn{5}{|c|}{ Time (Days) } \\
\hline & & & 0 & 14 & 30 & 60 & 90 \\
\hline $\begin{array}{l}\text { Visual } \\
\text { appearance }\end{array}$ & $\begin{array}{l}\text { Colour: Red } \\
\text { Clarity: Opaque } \\
\text { Odour: Orange }\end{array}$ & $\begin{array}{l}2-8^{\circ} \mathrm{C} \\
30{ }^{\circ} \mathrm{C}\end{array}$ & $\begin{array}{l}\text { Red, Opaque, } \\
\text { Orange } \\
\text { Red, Opaque, } \\
\text { Orange }\end{array}$ & $\begin{array}{l}\text { Red, Opaque, } \\
\text { Orange } \\
\text { Red, Opaque, } \\
\text { Orange }\end{array}$ & $\begin{array}{l}\text { Red, Opaque, } \\
\text { Orange } \\
\text { Red, Opaque, } \\
\text { Orange }\end{array}$ & $\begin{array}{l}\text { Red, Opaque, } \\
\text { Orange } \\
\text { Red, Opaque, } \\
\text { Orange }\end{array}$ & $\begin{array}{l}\text { Red, Opaque, } \\
\text { Orange } \\
\text { Red, Opaque, } \\
\text { Orange }\end{array}$ \\
\hline pH & 4 to 5 & $\begin{array}{l}2-8^{\circ} \mathrm{C} \\
30^{\circ} \mathrm{C}\end{array}$ & $\begin{array}{l}4.19 \\
4.19\end{array}$ & $\begin{array}{l}4.23 \\
4.60\end{array}$ & $\begin{array}{l}4.18 \\
4.71\end{array}$ & $\begin{array}{l}4.16 \\
4.81\end{array}$ & $\begin{array}{l}4.36 \\
4.78\end{array}$ \\
\hline Assay & $\begin{array}{l}90.0 \% \text { to } 110.0 \%(\text { USP } 2013) \\
\pm \text { SEM }\end{array}$ & $\begin{array}{l}2-8^{\circ} \mathrm{C} \\
30{ }^{\circ} \mathrm{C}\end{array}$ & $\begin{array}{l}100.0 \% \pm 0.0 \\
100.0 \% \pm 0.0\end{array}$ & $\begin{array}{l}109.6 \% \pm 7.1 \\
110.0 \% \pm 1.1\end{array}$ & $\begin{array}{l}105.6 \% \pm 8.0 \\
110.0 \% \pm 1.5\end{array}$ & $\begin{array}{l}110.0 \% \pm 7.2 \\
92.8 \% \pm 3.1\end{array}$ & $\begin{array}{l}99.4 \% \pm 2.5 \\
96.6 \% \pm 2.1\end{array}$ \\
\hline $\begin{array}{l}\text { Microbial } \\
\text { limit }\end{array}$ & $\begin{array}{l}\text { Aerobic bacteria }<1000 \mathrm{cfu} / \mathrm{g} \\
\text { Yeast \& mould }<100 \mathrm{cfu} / \mathrm{g}\end{array}$ & $\begin{array}{l}2-8^{\circ} \mathrm{C} \\
30{ }^{\circ} \mathrm{C}\end{array}$ & $\begin{array}{l}\text { Conforms } \\
\text { Conforms }\end{array}$ & $\begin{array}{l}\text { Conforms } \\
\text { Conforms } \\
\end{array}$ & $\begin{array}{l}\text { Conforms } \\
\text { Conforms } \\
\end{array}$ & $\begin{array}{l}\text { Conforms } \\
\text { Conforms } \\
\end{array}$ & $\begin{array}{l}\text { Conforms } \\
\text { Conforms } \\
\end{array}$ \\
\hline
\end{tabular}




\section{Discussion}

The suspension was prepared from capsules of rifampicin $300 \mathrm{mg}$. Nahata et al. (1994) described four preparation methods that can be used to prepare rifampicin suspension. In this study, we used one of the methods proposed which is triturating rifampicin capsule content in a portion of the carrier, adding more carriers, re-triturating the slurry and adding the remaining carrier while mixing. The authors reported that suspension prepared from capsules could lead to lower-than-expected rifampicin concentration as compared to those prepared from intravenous (IV) preparations (Nahata et al., 1994). In this study, we did not compare the stability of the preparations made from IV rifampicin, as the finding obtained from this study showed that the concentration of rifampicin remained above $90 \%$ of the original concentration throughout the course of study. The fluctuations in concentration are expected as presented in other previous studies (Baniasadi, Shahsavari, Namdar, \& Kobarfard, 2015; Nahata et al., 1994). However, the amount of the drug present in the formulation must be ensured to be within the accepted limit $(90 \%-110 \%)$ as outlined by pharmacopoeias.

Based on visual inspection, the rifampicin powder was properly wetted by the OSS and the suspension formed was thick and slurry-like. The presence of three suspending agents in $\mathrm{X}$-Temp ${ }^{\circledR}$ OSS, which are microcrystalline cellulose, carboxymethylcellulose sodium (CMC-Na) and xanthan gum, explains its effectiveness in ensuring the stability of the suspension and prevent caking of rifampicin powder at the bottom of the container. In compounded medications, microcrystalline cellulose is used as an adsorbent, a suspending agent and a capsule diluent (Marques-Marinho, F. D., \& ViannaSoares, C. D. 2013). In addition, microcrystalline cellulose is also considered as a component of the vehicle used for oral suspension (United States Pharmacopeia 2011). Marques-Marinho F. D., \& Vianna-Soares also reported in their publication that $\mathrm{CMC}-\mathrm{Na}$ acts as a capsule disintegrant, a stabilizer, a suspending agent, an emulsifying agent $(0.25-1 \%)$, a gelling agent $(3-6 \%)$ and a viscosity-increasing agent $(0.1-1 \%)$ in compounded medicines. Its application in compounding pharmacies is primarily due to its viscosity-increasing properties. Viscous aqueous solutions are used to suspend powders intended for either topical or oral use (Marques-Marinho, F. D., \& Vianna-Soares, C. D. 2013). Xanthan gum is described as anionic microbial polysaccharides, which is believed to have excellent performance in stabilizing suspensions as it will form gel-like network structure by intermolecular interaction (Xue, D., \& Sethi, R. 2012).

The X-Temp ${ }^{\circledR}$ OSS could also wet the rifampicin powder well. This ability is important as it relates to the dispersion of the powder and prevents fluctuations in the rifampicin concentrations. Previously reported work on rifampicin suspension by Nahata et al., (1994) showed the use of simple syrups was believed to have poor powder wettability, which contributed to a big fluctuation in rifampicin concentration available in the suspension over time, which is risky in the administration of drugs such as rifampicin (Nahata et al., 1994).

Dhanapal et al. (2012) reported on the formulation and evaluation of rifampicin suspension with single suspending agent. The authors used carboxymethylcellulose sodium, sodium starch glycolate, xanthan gum and carbomer 934, with the presence of flavouring agents and preservatives. It was shown that xanthan gum as a single suspending agent would give the best dispersion characteristics as compared to the others (Dhanapal, Manavalan, Chandar, \& Chenthilnathan, 2012). The combination of agents would undoubtedly improve the dispersion criteria, and this seems to be the case with X-temp ${ }^{\circledR}$ OSS.

The rifampicin suspension prepared by using Xtemp ${ }^{\circledR}$ OSS did not show any retained bubbles after shaking. There is no tendency of floating ingredients upon standing as compared to what mentioned by Haslam and his colleagues when they used Ora-Sweet ${ }^{\circledR}$, Ora-Plus ${ }^{\circledR}$ and simple cherry syrup as their suspension vehicle (Haslam, Egodage, Chen, Rajewski, \& Stella, 1999). Bubbles will affect the volume of preparation withdrawn; hence the presence of less bubbles is an advantage in liquid pharmaceuticals.

The $\mathrm{pH}$ of the rifampicin OSS was aimed at between 4 and 5. This is in accordance with the stability of rifampicin, which has been reported to be at the maximum between the two $\mathrm{pH}$ values (Haslam et al., 1999). It was also reported elsewhere that acetate buffers influence the degradation of rifampicin at over ten times degradation rate while chloroacetate and phosphate buffers degrade the drugs three times faster (K.C Jindal et al., 1995). X-temp ${ }^{\circledR}$ OSS contains citric acid and sodium acid phosphate as buffers. The presence of both ingredients will produce a citrate-phosphate buffer which is also known as McIlvaine buffer. The buffer system used in X-temp ${ }^{\circledR}$ OSS covers a $\mathrm{pH}$ range from 2.2 to 8.0. The presence of citric acid also serves as an antioxidant which will prevent the oxidative side reaction of rifampicin. The findings of this study as shown in Table 1, 2, 3 and 4 proved that the $\mathrm{pH}$ of rifampicin in X-temp ${ }^{\circledR}$ OSS remained at between $\mathrm{pH} 4$ and 5 throughout the study, which makes the X-temp ${ }^{\circledR}$ OSS a suitable carrier for this drug.

The rifampicin OSS also prepared void of any microbial contamination, despite being prepared at nonsterile room condition. This is an important characteristic of an oral extemporaneous preparation, as the shelf life of such product is usually limited by the growth of microorganisms besides the stability of the active 
ingredient itself. The incorporation of preservative(s) is usually needed for extemporaneous products to be safe and stable for a longer period. The preservatives used in this OSS covers a wide range of microorganisms, which is the reason for the absence of microbial contamination throughout the study period. Moreover, the $\mathrm{pH}$ of the OSS that maintained between 4 and 5 is also a non-favourable condition for the growth of common microorganisms, which might be an added value in the preservation of the rifampicin OSS (Jin \& Kirk, 2018).

Several publications reported on the stability of rifampicin extemporaneous preparation by using different syrups (Allen \& Erickson, 1998; Baniasadi et al., 2015; Krukenberg et al., 1986). The products were kept at either room temperature or under refrigeration. Krukenberg and coworkers showed a four-week stability period for $1 \%$ rifampicin suspensions formulated using Syrup NF, two commercially available simple syrup, wild cherry syrup and fruit-flavoured syrup. Allen Jr. L.V. and his team reported a stability period of four weeks for $1 \%$ rifampicin suspensions prepared using simple syrup, wild cherry syrup or fruit-flavoured syrup and stored under refrigeration. Baniasadi. S. and his colleagues also reported a stability period of 28 days (4 weeks) for a preparation of $120 \mathrm{~mL}$ of $10 \mathrm{mg} / \mathrm{mL}$ rifampicin (1\%) prepared by using simple syrup and stored under refrigeration. Nahata et al. (1994) found that rifampicin was stable in extemporaneous preparation for 56 days $(8$ weeks) in room temperature while a recent study by Cober et al. (2010) said that at least there are $99 \%$ of the initial rifampicin throughout the 60 days study period. The formulation was prepared by using rifampicin $20 \mathrm{mg} / \mathrm{ml}$ $(2 \%)$ in a mixture of Ora-Plus ${ }^{\circledR}$ with either Ora-Sweet ${ }^{\circledR}$ or Ora-Sweet SF and stored at room temperature (Cober, Johnson, Lee, \& Currie, 2010).

Concerning the X-Temp ${ }^{\circledR}$ OSS, the combination of different carefully chosen materials has managed to preserve the rifampicin and stabilize the suspension. The stability was shown to be preserved for 60 days in the open system. The type of bottles was previously described as an important factor in determining the stability of rifampicin suspension (Dhanapal et al., 2012). There were also reports on the increasing concentration of rifampicin during storage time, in which the authors believe that this is due to the binding of rifampicin to the plastic bottles and incomplete wetting and dispersion of the rifampicin powder during preparation (Baniasadi et al., 2015).

However, Allen and coworkers did not observe this. They reported that the stability of $25 \mathrm{mg} / \mathrm{mL}(2.5 \%)$ preparations of rifampicin, extemporaneously prepared in 3 vehicles; 1:1 Ora-Sweet:Ora-Plus, 1:1 Ora-Sweet SF:Ora-Plus, and cherry syrup, stored in polyethylene terephthalate (PET) prescription bottles in the dark was 28 days in both $5{ }^{\circ} \mathrm{C}$ and $25^{\circ} \mathrm{C}$ (Allen \& Erickson, 1998). This could mean that the binding of rifampicin to plastic bottles may happen with certain types of plastics. Hence, care must be taken to choose good plastic bottles such as PET and HDPE for storage to ensure that the concentration of rifampicin remains stable throughout the declared stability period. Another possible explanation would be that the suspension system itself has managed to prevent the adsorption of rifampicin on the bottles. This, however, would necessitate a more detailed study on the adsorption characteristics of the extemporaneous rifampicin suspension on different packaging materials.

\section{Conclusion}

The price of syrups used in extemporaneous preparations is an important factor being considered by healthcare institutions. The ability of a carrier system to ensure the stability of the product is also important. XTemp ${ }^{\circledR}$ OSS can help to maintain the stability of rifampicin extemporaneous preparations for up to 60 days in an open system and up to 90 days in a close system. In such practice, the patients do not need to visit the hospital too often to obtain their drug supply. The pharmacy department can also prepare stocks of rifampicin suspension and keep in a close system for up to 90 days. This is highly convenient and can increase the working efficiency in a busy pharmacy.

\section{Acknowledgements}

The authors acknowledged the contribution of Mr. Amiruddin Mat Jalil in providing the training to the students involved in conducting the microbiological assays, Mr. Mohd Asro Ramli for assisting the students in using the stability chamber and Puan Suhana Hairani Salleh and Puan Juwita Johari for assisting the students in the lab.

\section{Conflict of Interest}

The authors report no conflicts of interest. The authors alone are responsible for the content and writing of this article. The authors acknowledge the contribution of BioScenergy International Pv. Ltd. for supplying the Xtemp ${ }^{\circledR}$ OSS, rifampicin capsules and plastic HDPE bottles used in this study. 


\section{References}

Allen, L. V., Jr., \& Erickson, M. A. (1998). Stability of bethanechol chloride, pyrazinamide, quinidine sulfate, rifampin, and tetracycline hydrochloride in extemporaneously compounded oral liquids. American Journal of Health-System Pharmacy, 55(17), 1804-1809. doi:10.1093/ajhp/55.17.1804

ASEAN Traditional Medicines and Health Supplements Scientific Committee Meeting (ATSC). (2013). ASEAN Guideline on Stability Study of Drug Product. Retrieved from: https://www.npra.gov.my/images/Guidelines_Central /ASEAN_Common_Technical_Requirements_ACTR /ASEAN-Guideline-on-Stability-Study-of-DrugProduc-2013-2820th-ACCSQ-PPWG29.pdf

Baniasadi, S., Shahsavari, N., Namdar, R., \& Kobarfard, F. (2015). Stability assessment of isoniazid and rifampicin liquid dosage forms in a national referral center for tuberculosis. International Journal of Pharma Science and Research, 6(4), 706-709. Retrieved from http://www.ijpsr.info/docs/IJPSR1506-04-010.pdf

Cober, M. P., Johnson, C. E., Lee, J., \& Currie, K. (2010). Stability of extemporaneously prepared rifaximin oral suspensions. American Journal of Health-System Pharmacy, 67(4), 287-289. doi:10.2146/ajhp090206

Dhanapal, C. K., Manavalan, R., Chandar, N., \& Chenthilnathan, A. (2012). Formulation development of pediatric rifampicin oral suspension. Der Pharmacia Lettre, 4(3), 845-853.

Council of Europe. (2001). European Pharmacopoeia. Strasbourg: Council of Europe.

Glass, B., \& Haywood, A. (2006). Stability considerations in liquid dosage forms extemporaneously prepared from commercially available product. Journal of Pharmacy \& Pharmaceutical Sciences, 9(3), 398-426.

Haslam, J. L., Egodage, K. L., Chen, Y., Rajewski, R. A., \& Stella, V. (1999). Stability of rifabutin in two extemporaneously compounded oral liquids. American Journal of Health-System Pharmacy, 56(4), 333-336. doi:10.1093/ajhp/56.4.333

Jackson, M., \& Lowey, A. (2010). Handbook of Extemporaneous Preparation. London: Pharmaceutical Press.

Jindal, K., Chaudhary, R. S., K, S., Gangwal, S., \& Khanna, S. (1995). Effect of buffers and $\mathrm{pH}$ on Rifampicin stability. Die Pharmazeutische Industrie, $57,420-422$.
Jin, Q. \& Kirk, M.F. (2018). pH as a primary control in environmental microbiology: 1. Thermodynamic perspective. Frontiers in Environmental Science, 6(21). doi: 10.3389/fenvs.2018.00021

Krukenberg, C. C., Mischler, P. G., Massad, E. N., Moore, L. A., \& Chandler, A. D. (1986). Stability of $1 \%$ rifampin suspensions prepared in five syrups. American Journal of Hospital Pharmacy, 43(9), 2225-2228.

Marques-Marinho, F. D., \& Vianna-Soares, C. D. (2013). Cellulose and Its Derivatives Use in the Pharmaceutical Compounding Practice. In T. Ven \& L. Godbout (Eds.), Cellulose - Medical, Pharmaceutical and Electronic Applications (pp. 141162). doi: $10.5772 / 56637$

Nahata, M. C., Morosco, R. S., \& Hipple, T. F. (1994). Effect of preparation method and storage on rifampin concentration in suspensions. Annals of Pharmacotherapy, 28(2), 182-185. doi:10.1177/106002809402800204

Osol, A., \& Hoover., J. E. (1975). Remington's Pharmaceutical Sciences (Vol. 65, $15^{\text {th }}$ ed). Easton,Pennsylvania: Mack Publishing Co.

Quick, J. D., Hogerzeil, H. V., Rankin, J. R., Graham, M. N., Laing, R., Garnett, A., \& O'Connor, R. W. (1997). Managing drug supply: the selection, procurement, distribution, and use of pharmaceuticals. In J. D. Quick (Ed.), Management Sciences for Health in collaboration with the World Health Organization $\left(2^{\text {nd }}\right.$ ed., p. 816). West Hartford, Connecticut: Kumarian Press.

Tilinca, M., Hancu, G., Mircia, E., Iriminescu, D., Rusu, A., Vlad, R.A., \& Barabas, E. (2017). Simultaneous determination of isoniazid and rifampicin by UV spectrophotometry. Farmacia, 65(2), 219-224.

Rifampicin suspension. (2011). In United States Pharmacopeial Convention Committee of Revision (Ed.), United States Pharmacopeia - National Formulary $\left(35^{\text {th }}\right.$ ed., p. 1426). United States Pharmacopeial Convention.

Xue, D., \& Sethi, R. (2012). Viscoelastic gels of guar and xanthan gum mixtures provide long-term stabilization of iron micro- and nanoparticles. Journal of Nanoparticle Research, 14. doi:10.1007/S11051-0121239-0

Yalkowsky, Samuel H, \& He., Y. (2003). Handbook of Aquoues Solubility Data. Boca Raton, Florida: Journal of American Chemical Society. 